\title{
Reproductive aspects of Macrobrachium amazonicum (Decapoda: Palaemonidae) in the State of Amapá, Amazon River mouth
}

\author{
Jô de Farias LIMA ${ }^{1 *}$, Luis Mauricio Abdon da SILVA², Thibério Carvalho da SILVA, \\ Jamile da Silva GARCIA3 ${ }^{3}$ Ilana da Silva PEREIRA³ ${ }^{3}$, Karlia Dalla Santa AMARAL ${ }^{1}$ \\ Empresa Brasileira de Pesquisa Agropecuária - Embrapa Amapá. Rodovia Juscelino Kubitschek, km 5, n²600, CEP: 68906-970, Caixa Postal 10, Phone: (96) 4009-9546, Fax: \\ (96) 4009-9501. Macapá, Amapá, Brazil. \\ 2 Instituto de Pesquisas Cientificas e Tecnológicas do Estado do Amapá, Campus da Fazendinha. Rodovia Juscelino Kubitschek, km 10, Fazendinha, CEP: 68903-419/68903-197, \\ Phone: (96) 32125350. Macapá, Amapá, Brazil. luis.mauricio@iepa.ap.gov.br; \\ ${ }^{3}$ Universidade do Estado do Amapá, Curso de Engenharia de Pesca. Av. Presidente Vargas, nº 650, CEP: 68900-000, Phone: (96) 21010515/21010506. Macapá, Amapá, Brazil, \\ milyeminem@hotmail.com, pereirailana1@gmail.com; \\ ${ }^{4}$ Universidade do Oeste do Paraná-Unioeste/Toledo, Grupo de Estudos de Manejo na Aquicultura - GEMAq, Rua da Faculdade, 645. Jd. Santa Maria, CEP 85903-160. Toledo, \\ Paraná, Brazil. thiberiocs@hotmail.com; \\ *Corresponding Author: jo.lima@embrapa.br
}

\begin{abstract}
Macrobrachium amazonicum is an indigenous prawn vastly distributed in basins of South America, widely exploited by artisanal fisheries in northern and northeastern Brazil and, with great potential for aquaculture. This study aimed to investigate general aspects of population structure and reproductive characteristics (size at first maturity, fecundity and reproductive output) of $M$. amazonicum from two important areas to artisanal prawn fishing located at the mouth of the Amazon River, State of Amapá. The specimens were captured using 20 handcrafted traps called "matapi”. A number of 5,179 prawns were captured, 2,975 females and 2,195 males resulting in 1.35:1 female to male ratio. Santana Island and Mazagáo Velho showed females predominated in the population. A reproductive peak period was observed from January to April/2009 and in December/2010, coinciding with the period of higher rainfall. The recruitment peak occurred in June and July/2009. Egg-bearing females ranged in size (carapace length) from 11.10 to $29.6 \mathrm{~mm}$. Fecundity increased with female size and reached up to 7,417 eggs. This amount of eggs is considered low if compared with other Macrobrachium estuarine species. Mean egg volume increased gradually from 0.121 to $0.24 \mathrm{~mm}^{3}$ during embryogenesis, representing $68.5 \%$ of overall increase from Stage I to Stage III. Eggs of M. amazonicum are small; this is typical for Macrobrachium species, which depends on brackish water to complete the larval development. Irrespective of female size, reproductive output of M. amazonicum varied between 4.8 and $21.85 \%$ of their body weight into eggs production.
\end{abstract}

KEYWORDS: Palaemonid eggs, first maturation, fecundity, morphometric relationships, reproduction

\section{Aspectos reprodutivos do camarão Macrobrachium amazonicum (Decapoda: Palaemonidae) no estado do Amapá, foz do rio Amazonas}

\begin{abstract}
RESUMO
Macrobrachium amazonicum é uma espécie nativa vastamente distribuída nas bacias da America do Sul, sendo largamente explorada por pescadores artesanais no Norte e Nordeste do Brasil e com grande potencial para aquicultura. O objetivo deste trabalho foi abordar aspectos gerais da estrutura populacional e biologia reprodutiva (tamanho de primeira maturação, fecundidade e investimento reprodutivo) de $M$. amazonicum de duas importantes áreas de pesca artesanal de camaráo localizada na foz do rio Amazonas, no Estado do Amapá. Os exemplares foram capturados usando 20 armadilhas artesanais, conhecidas localmente como matapi. Um total de 5.179 camaróes foi capturado, dos quais 2.975 eram fêmeas e 2.195 eram machos, dando uma razão sexual geral de 1,35: 1 em favor das fêmeas. As proporçóes sexuais nas áreas de Ilha de Santana e Mazagáo mostraram fêmeas predominando na populaçáo. Os picos reprodutivos nas duas áreas ocorreram de Janeiro a Abril/2009 e em Dezembro/2010, coincidindo com o período mais chuvoso. Os picos de recrutamento foram observados em junho e julho de 2009. O tamanho das fêmeas ovígeras variou de $11,10 \mathrm{~mm}$ a 29,6 $\mathrm{mm}$ de comprimento de carapaça. A fecundidade aumentou com o tamanho das fêmeas, chegando até 7.417 ovos, podendo ser considerada baixa comparada a outras espécies estuarinas de Macrobrachium. Volume médio dos ovos aumentou gradualmente durante a embriogênese saindo de 0,112 para $0,220 \mathrm{~mm}^{3}$, representando um aumento global de $68,5 \%$ do I ao III estágio embrionário. Os ovos de M. amazonicum podem ser considerados pequenos, típicos de espécies de Macrobrachium que dependem de água salgada para completar seu desenvolvimento larval. Independente do tamanho da fêmea, o investimento reprodutivo de M. amazonicum variou entre 4,8 e $21,85 \%$ do seu peso corporal para a produção de ovos.
\end{abstract}

PALAVRAS-CHAVE: ovos de palaemonideos, primeira maturação, fecundidade, relaçôes morfométricas, reprodução. 


\section{INTRODUCTION}

Prawns are decapods restricted to freshwater or need brackish water on the onset of life cycle (New 2002). Unlike marine shrimp, female prawns carry their eggs until spawning time. Among palaemonid prawns, the genus Macrobrachium (Bate 1868) is one of the most important groups worldwide with many species of scientific and commercial interest distributed in tropical and subtropical regions (Da Silva et al. 2004; Silva el al. 2007).

The knowledge of reproductive biology (fecundity and fertility) of palaemonid prawns is an important tool to evaluate the potential candidates for aquaculture and define strategies for biodiversity preservation (Mossolin and Bueno 2002). Therefore, understanding the reproductive periodicity of this group is imperative for developing management and culture programs with obvious consequences for species conservation policies (Fransozo et al. 2004).

In Palaemonid species fecundity can be defined as the number of eggs laid per hatching that can be found adhered to the female pleopods. According to Valenti et al. (1989), the knowledge of species fecundity is important to evaluate their potential for commercial farming, as well as estimating the reproductive potential and stock size of natural population. In addition, it can also be used to determine the minimum number of adults necessary to maintain the recruitment and egg survival rates until adulthood (Da Silva et al. 2004).

Macrobrachium amazonicum (Heller 1862) is an indigenous species vastly distributed in many basins of South America (Gamba 1997). This prawn species had great economic importance. It is widely exploited by artisanal fisheries in northern and northeastern Brazil, and it is broadly consumed by indigenous people and Brazilians of all economic groups (Moraes-Riodades and Valenti 2002). Because of its potential for aquaculture, intense research effort has been made elsewhere to determine the general reproductive aspects of this species, especially for the North region of Brazil (Chaves and Magalhães 1993; Silva et al. 2002; Da Silva 2011). Moreover, in these reports neither the authors provide information on female energy investment per egg clutch, nor they consider the different developmental stages of eggs.

Despite the high biological and economic importance of $M$. amazonicum in the Amazon region, its life history is poorly understood especially in the region of Amapá state, Brazil. Therefore, studies on this species are necessary to develop appropriate farming technology for Brazilian North region and thus, enabling farmers to have alternative species for culture. This study aimed to investigate general aspects population structure and reproductive biology (reproductive period, size of sexual maturity population, fecundity individual and population, reproductive output

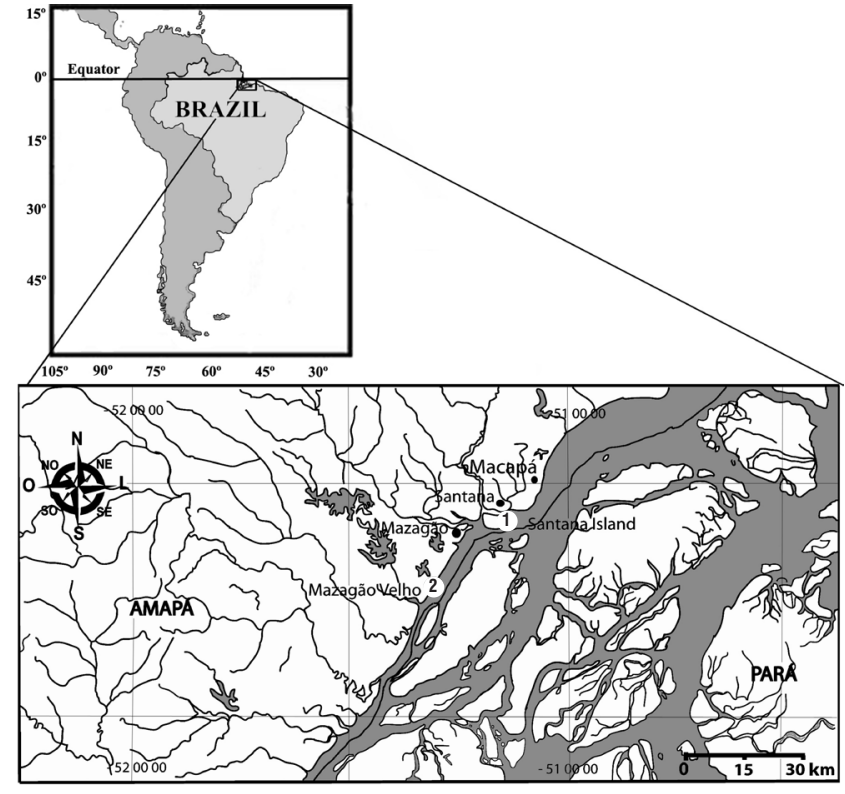

Figure 1 - Study area location - 1) Santana island, 2) Mazagão Velho.

and recruitment) of $M$. amazonicum from two important areas to artisanal prawn fishing located at the mouth of the Amazon River, State of Amapá.

\section{MATERIALS AND METHODS}

\section{Study Area}

The study area comprised the regions of Santana Island (0003'40.9"S and 051 $08^{\circ}$ '46.6”'W) and Mazagáo Velho $\left(00^{\circ} 15^{\prime} 39.9^{\prime \prime} \mathrm{S}\right.$ and $\left.051^{\circ} 20^{\prime} 42.3^{\prime} \mathrm{W}\right)$ located in the estuary of the Amazon River, State of Amapá (Figure 1). The areas are relatively similar and important to artisanal prawn fishing. Santana Island is more exploited than Mazagão Velho. These islands have various drainage channels with different sizes and depths influenced by the tidal flooding, generating a wide diversity of microhabitats. In Santana Island, vegetation is open and sparse, with the presence of a narrow border of macrophytes. In Mazagão Velho, the vegetation is strongly dense with great and wide bands of macrophytes along the river.

\section{Samples collection and Rainfall data}

Samples were collected monthly from January 2009 to January 2010 by using an artisanal trap called "matapi" (25 $\mathrm{cm}$ in diameter and $50 \mathrm{~cm}$ in length, spacing of cracks between 3 to $5 \mathrm{~mm}$ ), baited with flour of babaçu (Orbignya speciosa.) palm fruit as reported by Simonian (2006). Twenty matapis were used at each collection site. Traps were set at depths of 1 to 2 meters during on average 12 hours of immersion. The sampling method is equivalent to the capture performed by artisanal fishermen every tidal cycle ( $12 \mathrm{~h}$, twice daily). All 
Table 1 - Distribution frequency and grouped percentage of adult (males, non-ovigerous females, ovigerous females) and juvenile prawns (males, females and undifferentiated sex) of Macrobrachium amazonicum sampled in Santana Island and Mazagão Velho from Jan/2009 to Jan/2010.

\begin{tabular}{|c|c|c|c|c|c|c|c|c|c|c|c|c|c|c|}
\hline \multirow{3}{*}{ Study site } & \multicolumn{6}{|c|}{ Adult prawns } & \multicolumn{6}{|c|}{ Juvenile prawns } & & \\
\hline & \multicolumn{2}{|c|}{ Male } & \multicolumn{2}{|c|}{$\begin{array}{l}\text { Non-ovig. } \\
\text { Female }\end{array}$} & \multicolumn{2}{|c|}{$\begin{array}{l}\text { Ovig. } \\
\text { Female }\end{array}$} & \multicolumn{2}{|c|}{ Male } & \multicolumn{2}{|c|}{ Female } & \multicolumn{2}{|c|}{ Und. sex } & \multicolumn{2}{|c|}{ Total } \\
\hline & $\mathrm{N}$ & $\%$ & $\mathrm{~N}$ & $\%$ & $\mathrm{~N}$ & $\%$ & $\mathrm{~N}$ & $\%$ & $\mathrm{~N}$ & $\%$ & $\mathrm{~N}$ & $\%$ & $\mathrm{~N}$ & $\%$ \\
\hline $\begin{array}{l}\text { Santana } \\
\text { Island }\end{array}$ & 1,537 & 29.7 & 1,328 & 25.6 & 684 & 13.2 & 161 & 3.1 & 236 & 4.6 & 3 & 0.06 & 3,949 & 76.3 \\
\hline $\begin{array}{l}\text { Mazagão } \\
\text { Velho }\end{array}$ & 426 & 8.2 & 346 & 6.7 & 206 & 4.0 & 71 & 1.4 & 175 & 3.4 & 6 & 0.11 & 1,230 & 23.7 \\
\hline Total & 1,963 & 37.9 & 1,674 & 32.3 & 890 & 17.2 & 232 & 4.5 & 411 & 7.9 & 9.00 & 0.17 & 5,179 & 100 \\
\hline
\end{tabular}

captures occurred at daybreak. The caught specimens were properly labeled and preserved in plastic bags containing $4 \%$ formalin $+70 \%$ ethanol $(1: 1)$ solution. The monthly rainfall data in the region was obtained at the Nucleus of Hydrometeorology and Renewable Energy of Institute of Scientific and Technological Research of the State of Amapá - IEPA (NHMET/IEPA).

\section{Laboratory work}

In the laboratory, prawns were sorted into species and identified according to Melo (2003). Carapace length and total length were measured with digital caliper (Absolute 500196-20, Mitutoyo, Tokyo City, Japan) at $0.01 \mathrm{~mm}$ precision, and the body wet weight of each individual was determined by a semi-analytic scale with $0.01 \mathrm{~g}$ precision (BL $320 \mathrm{H}$, Shimadzu, Harbour City, Hong Kong). Carapace length was measured as the distance from the inside of the eye socket to the center of the dorsal margin of the carapace, whereas total length was measured as linear distance from the rostrum extremity to the telson tip. Prawns were grouped into the following demographic categories: adult males, non-ovigerous adult females, ovigerous and juveniles (smaller prawns than the smallest ovigerous female and undifferentiated sex). Sexual differentiation was assessed by observing the secondary sexual characteristics, such as male appendix in the second pleopods, which is absent in females.

\section{Reproductive aspects}

The reproductive period was determined by the presence of ovigerous females during the sampling period. Size at first individual maturity was determined between the size classes with smaller ovigerous female. The size for sexual maturity population was determined among size classes with $50 \%$ of ovigerous females. The fecundity was obtained by direct counting the eggs of 49 ovigerous females that were randomly selected considering the integrity of eggs and collection months. The entire egg mass was carefully removed under a dissecting binocular stereo microscope ( $\mathrm{K}$ 400L, Motic, Causeway Bay, Hong Kong) and all eggs were counted. The development stages of eggs was sorted as follows
(Wehrtmann 1990): Stage I: eggs recently extruded; uniform yolk; no eye pigments visible; Stage II: eye pigments barely visible, and Stage III: eyes clearly visible and fully developed. The recruitment was assessed by the presence of juvenile individuals in the sampled population.

To determine the egg volume, a total of 10 eggs were separated from each ovigerous female to measure the length (longest axis) and width (shortest axis) under a compound binocular microscope equipped with calibrated ocular micrometer. Egg volume was calculated according to Wehrtmann (1990) by the following formula:

$$
\mathrm{v}=\pi^{*} \mathrm{l}^{*} \mathrm{~h} *(\mathrm{~h})^{2}
$$

Where "l" is length; " $h$ " width in mm e $\pi=3.14$

For reproductive output (RO), the dry mass of each ovigerous female was determined with a digital balance without regard to the developmental stage of the embryos; subsequently, the $\mathrm{RO}$ was calculated by dividing the total egg wet mass by the female wet mass that were determined by analytic scale $(0.0001 \mathrm{~g}$ precision $)$.

\section{Statistical analysis}

The differences in monthly abundance between areas were analyzed using the Student test (Zar 1999). The differences in sex ratio were analyzed and tested for significant divergence from the expected 1:1 ratio by using the Chi-square $(\chi 2)$ goodness off it test (Zar 1999). Pearson linear regression model with a posteriori Student test was used to demonstrate the correlation between total weight and total length and, total length and carapace length. Other Pearson linear regression model with a posteriori Student t test was used to demonstrate the correlation between body size and number and, mass volume of incubated eggs for each embryonic stage. For each of the three embryonic stages, the mean egg volume with standard deviation was calculated and the Analysis of variance (ANOVA, $\alpha=0.05$ ) with a posteriori Tukey test was applied to identify significant differences between stages (Zar 1999). The mean egg volume was subsequently multiplied by the total number of eggs per female to obtain the total egg mass; linear regressions were prepared for each embryonic stage to depict 
Table 2 - Chi-square values and sex ratio of Macrobrachium amazonicum sampled in Santana Island and Mazagão Velho from Jan/2009 to Jan/2010.

\begin{tabular}{|c|c|c|c|c|c|c|c|c|c|c|c|c|}
\hline \multirow[b]{2}{*}{ Months } & \multicolumn{4}{|c|}{ Santana Island } & \multicolumn{4}{|c|}{ Mazagão } & \multicolumn{4}{|c|}{ Sites Grouped } \\
\hline & q & $\hat{0}$ & $x^{2}$ & Ratio & q & $\hat{\sigma}$ & $x^{2}$ & Ratio & q & $\sigma^{\lambda}$ & $x^{2}$ & Ratio \\
\hline Jan/09 & 105 & 31 & 40.3 & $3.4: 1^{*}$ & 8 & 4 & 1.3 & $2.0: 1$ & 113 & 35 & 45.7 & $3.3: 1$ * \\
\hline Feb & 288 & 75 & 125.0 & $3.8: 1^{*}$ & 124 & 84 & 7.7 & $1.47: 1^{*}$ & 412 & 159 & 226.1 & $2.6: 1^{\star}$ \\
\hline Mar & 175 & 71 & 44.0 & $2.5: 1^{*}$ & 52 & 90 & 10.2 & $0.57: 1^{*}$ & 227 & 161 & 75.1 & $1.4: 1^{\star}$ \\
\hline Apr & 51 & 59 & 0.58 & $0.9: 1$ & 13 & 22 & 2.3 & $0.59: 1$ & 64 & 81 & 0.1 & $0.8: 1$ \\
\hline May & 145 & 165 & 1.3 & $0.9: 1$ & 20 & 17 & 0.3 & $1.18: 1$ & 165 & 182 & 0.0 & $0.9: 1$ \\
\hline Jun & 43 & 26 & 4.2 & $1.6: 1^{*}$ & 40 & 26 & 3.0 & $1.54: 1$ & 83 & 52 & 27.9 & $1.6: 1^{\star}$ \\
\hline Jul & 242 & 82 & 79.0 & $2.9: 1^{*}$ & 155 & 82 & 22.5 & $1.89: 1^{*}$ & 397 & 164 & 188.2 & $2.4: 1^{*}$ \\
\hline Aug & 280 & 258 & 0.9 & $1.1: 1$ & 60 & 45 & 2.2 & $1.33: 1$ & 340 & 303 & 10.9 & $1.1: 1$ \\
\hline Sept & 359 & 329 & 1.3 & $1.1: 1$ & 35 & 8 & 16.9 & $4.37: 1^{\star}$ & 394 & 337 & 4.4 & $1.2: 1^{\star}$ \\
\hline Oct & 275 & 223 & 5.4 & $1.2: 1^{*}$ & 62 & 75 & 1.2 & $0.83: 1$ & 337 & 298 & 22.9 & $1.1: 1$ \\
\hline Nov & 58 & 81 & 3.8 & $0.7: 1$ & 11 & 15 & 0.6 & $0.73: 1$ & 69 & 96 & 1.0 & $0.7: 1^{*}$ \\
\hline Dec & 214 & 281 & 9.1 & $0.8: 1^{*}$ & 104 & 17 & 62.5 & $6.12: 1^{*}$ & 318 & 298 & 0.1 & $1.1: 1$ \\
\hline Jan/10 & 13 & 17 & 0.5 & $0.8: 1$ & 44 & 12 & 18.3 & $3.66: 1^{*}$ & 57 & 29 & 11.5 & $2.0: 1^{\star}$ \\
\hline
\end{tabular}

*Significant data, $\mathrm{P}<0.05$.

the relation between fecundity and females' size (FS). Linear regressions were prepared to analyze the relation between $\mathrm{RO}$ and female size (TL). All statistical analyses were conducted using the Biostat 5.0 software at $\alpha=0.05$.

\section{RESULTS}

In the present study 5,179 specimens of $M$. amazonicum were captured, 2,975 females and 2,195 males, resulting in a female to male sex ratio of 1.35:1. Global number of prawns caught in Santana was higher than in Mazagão $(\mathrm{P}<$ 0.05) (Table 1). The Chi-square test showed that the ratio was significantly different from that (1:1) in Santana Island $\left(\mathrm{X}^{2}=76.66\right.$; $\left.\mathrm{P}<0.001\right)$ and Mazagão Velho $\left(\mathrm{X}^{2}=43.56\right.$; $\mathrm{P}<$ 0.001 ), with 1 o 1.46 q and 1 : 1.32 \% respectively. M. amazonicum showed significant differences from a $1 \hat{0}: 1$ 우 ratio except in April, May, August, October and December 2009 (Table 2).

There was increased capture rate during summer (August to October), particularly for adult prawns, matching with the period of higher fish production in the region (Figure 2). Ovigerous $M$. amazonicum females were found throughout the year; however, the reproductive peak period was from January to April 2009 and December 2009, coinciding with high rainfall (Figure 2). Juvenile prawns were found in most months of the year; but the recruitment peak was observed in June and July, with capture of $76.7 \%$ of juveniles.

The largest female showed $29.6 \mathrm{~mm}$ of carapace length or it was $146.48 \mathrm{~mm}$ total length, whereas the largest male was $32.92 \mathrm{~mm}$ or $165.11 \mathrm{~mm}$ total length. The biometrical relationships between the total weight (TW) and total length (TL), and between the TL and carapace length (CL) of both sexes were statistically significant $(\mathrm{P}=0.95)$ (Figures $3 \mathrm{~A}$ and 3B).

Among females sampled, 890 or $31.56 \%$ carried eggs in their abdomen and 1,930 or $68.44 \%$ did not. Ovigerous females ranged in carapace length from 11.10 to $29.6 \mathrm{~mm}$, out of which $52.5 \%$ are distributed between classes of 11.10 to $19.09 \mathrm{~mm}$, suggesting that the first gonad maturation of M. amazonicum populations from Santana Island and Mazagão occurs between these classes (Table 3).

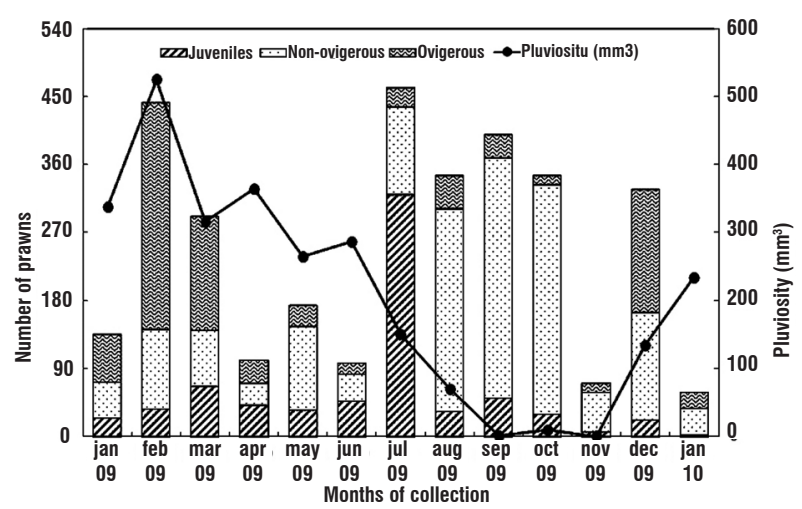

Figure 2 - Absolute frequency distribution of ovigerous, non-ovigerous females and juveniles of Macrobrachium amazonicum sampled in Santana Island and Mazagão Velho from Jan/2009 to Jan/2010. 

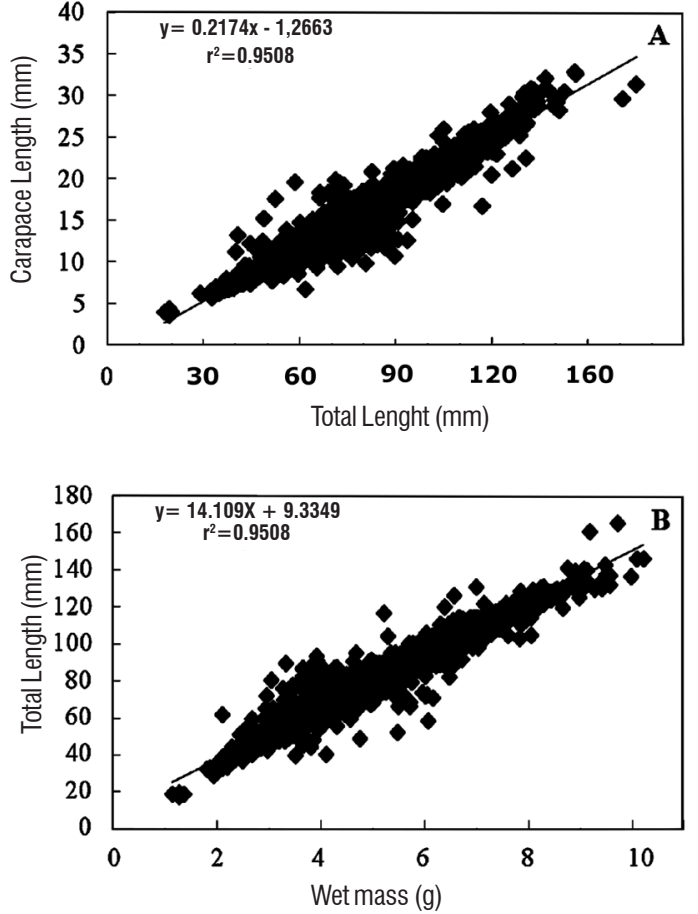

Figure 3 - Biometric ratios between male and female of Macrobrachium amazonicum sampled in Santana Island and Mazagão Velho from Jan/2009 to Jan/2010. A - total length and total weight; B - carapace length and total length.
The estimated fecundity of $M$. amazonicum varied between 1,099 and 7,417 eggs per specimen for individuals of 15.38 $29.6 \mathrm{~mm}$ carapace length or $75.30-146.48 \mathrm{~mm}$ total length. The body size parameter was considered more suitable than body weight as the independent variable for correlation with egg number because the latter parameter may be significantly influenced by the loss of one or both second of pereiopods that occurred in some females during transportation from the collecting site to the laboratory. The relationship between fecundity (egg number and mass volume) and female size (carapace length) can best be described by a positive linear correlation for Stage I (egg number with $\mathrm{P}<0.001$ and egg mass volume with $\mathrm{P}<0.001$ ); Stage II (egg number with $\mathrm{P}=$ 0.00024 and egg mass volume with $\mathrm{P}=0.00049$ ) and Stage III (egg number with $\mathrm{P}=0.0018$ and egg mass volume with $\mathrm{P}=0.0032$ ) (Figure 4).

The ANOVA test showed significant difference between egg stages $(\mathrm{P}<0.001)$, with mean egg length having increased from 0.38 at Stage I to $0.48 \mathrm{~mm}$ at Stage III (Table 4). Mean egg volume increased significantly during embryogenesis $(\mathrm{P}<0.001)$ from 0.121 to $0.204 \mathrm{~mm}^{3}$, representing $68.6 \%$ the overall global increase, approximately $30 \%$ at each stage (Table 4). There was no statistically significant relationship (P $=0.92$ ) between $\mathrm{RO}$ and $\mathrm{CL}$ in $M$. amazonicum, indicating

Table 3 - Distribution frequency of Macrobrachium amazonicum according to the size classes (Carapace Length) sampled in Santana Island and Mazagão Velho from Jan/2009 to Jan/2010.

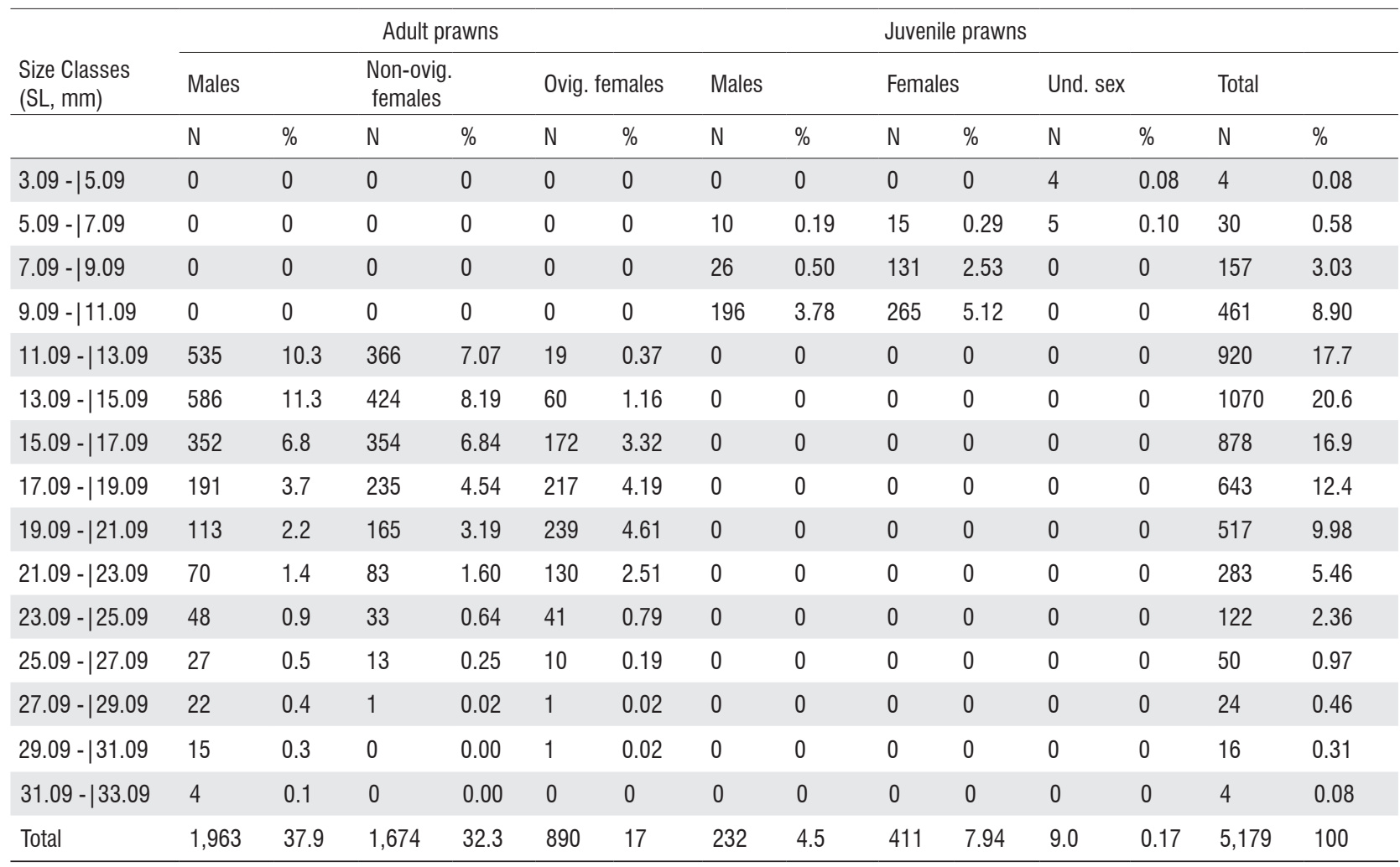



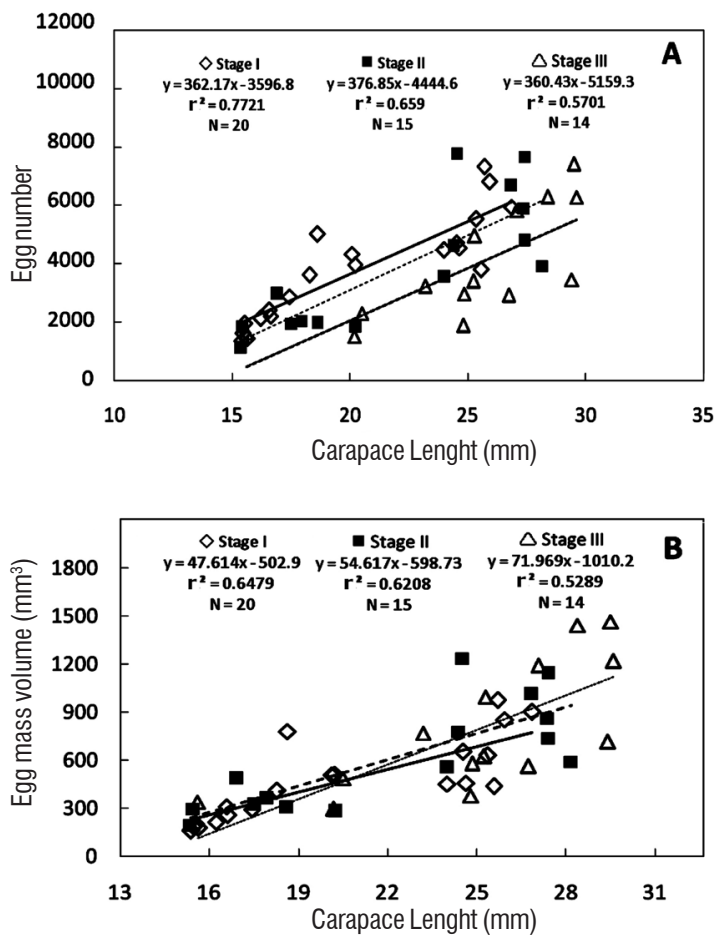

Figure 4 - Ratio between fecundity and female size for each of the three embryonic stages of Macrobrachium amazonicum sampled in Santana Island and Mazagão Velho from Jan/2009 to Jan/2010. A - carapace length (mm) and egg number $(\mathrm{mm})$; B - carapace length $(\mathrm{mm})$ and egg mass volume $(\mathrm{mm}$ 3). Stage I: solid line; Stage II: dashed line; Stage III: dotted line.

that $\mathrm{RO}$ is not determined by size (Figure 4). Females of this species converted on average $11.74 \%$ of their body weight into the eggs production, and $\mathrm{RO}$ varied between $4.8 \%$ and $21.85 \%$ (Figure 5).

\section{DISCUSSION}

In this study females predominated in the population. This biased-female ratio seems to be common in caridean prawns, particularly in species of the Macrobrachium genus. For example, high proportion of females has also been reported in M. olfersii (Mossolin and Bueno 2002), M. potiuna (Antunes and Oshiro 2004) and M. iheringi (Fransozo et al. 2004). However, the ratio in favor of males or identical proportion of males and females can also be observed in this genus. For $M$. hainanense in Hong Kong streams by Mantel and Dundgeon (2005) and (Parisi 1919) that deviations at sex ratio were in favor of males. Moreover, identical proportion of males and females was recorded by Mattos and Oshiro (2009) for $M$. potiuna (Müller 1880), in which the sex ratio did not differ from the expected $10: 1$. be a consequence of differences in size, mortality and birth rates between males and females or other factors, such as
Table 4 - Egg volume $\left(\mathrm{mm}^{3}\right)$ and Egg size $(\mathrm{mm})$ with mean, minimum and maximum values for three embryonic developmental egg stages of Macrobrachium amazonicum sampled in Santana Island and Mazagão Velho from Jan/2009 to Jan/2010. N = number of observations; SD = standard deviation.

\begin{tabular}{|c|c|c|c|c|c|}
\hline $\begin{array}{l}\text { Egg } \\
\text { stage }\end{array}$ & $\mathrm{N}$ & $\begin{array}{c}\text { Mean egg volume } \\
\left(\mathrm{mm}^{3}\right)\end{array}$ & $\pm \mathrm{SD}$ & Minimum & Maximum \\
\hline I & 20 & 0.121 & 0.016 & 0.101 & 0.156 \\
\hline ॥ & 15 & 0.158 & 0.009 & 0.146 & 0.178 \\
\hline III & 14 & 0.204 & 0.015 & 0.184 & 0.238 \\
\hline $\begin{array}{l}\text { Egg } \\
\text { stage }\end{array}$ & $\mathrm{N}$ & Mean egg length $(\mathrm{mm})$ & $\pm S D$ & Minimum & Maximum \\
\hline I & 20 & 0.383 & 0.016 & 0.354 & 0.407 \\
\hline ॥ & 15 & 0.435 & 0.023 & 0.386 & 0.478 \\
\hline III & 14 & 0.480 & 0.019 & 0.464 & 0.536 \\
\hline
\end{tabular}

molt rates, dispersal, reproduction and differential migration (Botelho et al. 2001).

Among populations of a same species, the sex ratio also may be influenced by environmental conditions, geographical characteristics and anthropogenic interferences. For example, Odinetz-Collart (1991) clearly shows the effects of a dam construction on $M$. amazonicum population from the lower Tocantins (State of Pará), with reduced specimens' size and sex ratio. Similarly, Silva et al. (2002) suggest a possible overexploitation affecting the population dynamics of this prawn species on the island of Combú (State of Pará).

Bentes et al. (2011) showed that abundance of $M$. amazonicum of two perennial creeks from Guajará Bay may be associated to the greater opportunities for refuge and availability of food sources. In the present study, differences in capture of $M$. amazonicum specimens between areas probably may not be related to the food availability, once the areas are relatively similar, with the same tidal dynamics and food resources. On the other hand, Mazagáo area has greater abundance of macrophytes and greater opportunities for refuge from predation, consequently the prawns in this area can be less susceptible to capture than in Santana Island.

The M. amazonicum fishery is characterized by periods of abundance and scarcity referred by local fishermen as "harvest season" (safra) and "slack" or "between-harvest season" (entressafra) (Maciel and Valenti 2009). According to the local fishermen, the capture of prawns is impaired during the high-water (flood) period, due to the strong currents and dispersal of prawns in the lowland. The prawns are caught in abundance along the banks of the Amazon River during low water, when they are migrating from the lowland (present study). Similar data are presented by Bentes et al. (2011), suggesting that these prawns catches are strongly influenced by rainfall on the lower Amazon River estuary. 


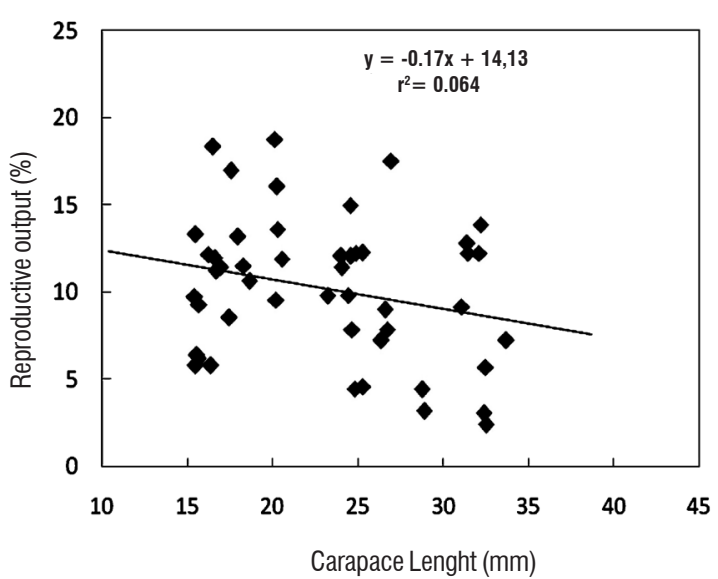

Figure 5 - Ratio between female carapace length $(\mathrm{mm})$ and reproductive output of Macrobrachium amazonicum considering all developmental egg stages.

Regarding the ovigerous females, the smallest specimen was caught on Santana Island and had $11.10 \mathrm{~mm}$ of carapace length or it was $5.5 \mathrm{~cm}$ total length, being larger than that length described by Silva et al. (2002) in the municipality of Vigia $(C T=2.5 \mathrm{~cm})$ and Bentes et al. (2011) on Combu Island. These results suggest that these areas are favorable to breeding and attract females of all sizes. The occurrence of ovigerous females in all monthly samples indicates that the M. amazonicum population from Santana Island and Mazagão reproduces continuously year-round. This observation is similar to that of Silva et al. (2002), Sampaio et al. (2007) and Bentes et al. (2011) for samples collected in various regions of Brazil.

The reproductive period of freshwater decapod crustaceans is closely associated with the rainy period, thermal variations and photoperiod of the region where it happens. Similar to the present study, ovigerous females of M. amazonicum have been found over the year with the reproductive peak in the rainy season, especially in estuarine populations (Silva et al. 2005; Silva et al. 2007, Bentes et al. 2011). In contrast, no relationship with rainfall was observed in populations from Jaguaribe River in northeastern Brazil by Sampaio et al. (2007), indicating atypical behavior of this species in the region, probably due to the local arid climate.

The size at first sexual maturity shown in the present work was similar to the standard range reported for the species, which is between $45-60 \mathrm{~mm}$ total length (Moraes-Riodades and Valenti 2002; Silva et al. 2005; Sampaio et al. 2007). In other estuarine area of Amazon River with intensive fishing activity, $M$. amazonicum ovigerous females have been reported with much smaller sizes than those in the present study (Silva et al. 2002; Silva et al. 2007), indicating that this species is overfished.
According to the local fishermen, the volume and size of prawns caught have decreased considerably in the last decade. Based on that, $30.1 \%$ of prawns caught in the matapis have 3.9 to $13.9 \mathrm{~mm}$ of carapace length (Table 3), and whereas up to $65.0 \mathrm{~mm}$ total length $M$. amazonicum is capable of performing at least one reproduction, one can infer that ideal size for first catch is $70.0 \mathrm{~mm}$ total length. Additionally, based on the data presented by Camargo et al. (2009) and Da Silva (2011), one can suggested adjustment in the spacing of cracks matapis, which currently present 2 to $3 \mathrm{~mm}$ for minimum distances of 8 and $10 \mathrm{~mm}$. Once performed such adjustment, the number of juvenile prawns caught will probably decrease considerably.

Recruitment is a complex process involving a chain of events in the life cycle of the prawns (Deekae and Abowei 2010). The recruitment occurs when an age group integrates for the first time into the exploitable stock. In this context, about $70.7 \%$ of $M$. amazonicum juveniles caught in the present study integrated for the first time into the exploitable stock between sizes 9.09 and $11.09 \mathrm{~mm}$ of carapace length.

According to Lara and Wehrtmann (2009), caridean prawns are not as productive in fisheries and aquaculture as penaeids and fecundity is much higher in penaeids than in carideans. In the estuarine Macrobrachium species that depends on estuarine environments to complete the larval development, this generalization is not observed (Lara and Wehrtmann 2009; Bentes et al. 2011). These species can attain large sizes and produce much more eggs than the majority of other caridean prawns.

The highest fecundity in species of genus Macrobrachium is observed in M. rosembergii (De Man 1879) and M. carcinus (Linnaeus 1758), whose females can lay between 14,000 and 242,000 eggs in each spawning when they are complete mature (Lara and Wehrtmann 2009). Although M. amazonicum captured in Santana Island and Mazagão presents lower fecundity than those species; it has higher fecundity than M. lanchesteri with 58-580 eggs (Phone et al. 2005), $M$. hainanense with 20-75 eggs (Mantel and Dudgeon 2005), $M$. brasiliense (Heller 1862) with 15-168 eggs (Garcia-Dávila et al. 2000) among other Macrobrachium species reported by Lobão et al. (1986) whose absolute fecundity is lower than 200 eggs.

The intra- and interespecific differences in fecundity for representatives of the genus Macrobrachium are influenced by the differences in female size (Graziani et al. 1993; Da Silva et al. 2004) depending on temperature, food quality and quantity, which may vary along the latitudinal range of species distribution (Fransozo et al. 2004), proximity to estuarine regions.

In estuarine species, such as $M$. carcinus and $M$. rosembergii, there is a visible increased size of animals, number of eggs and larval stages; contrary to the typical species of continental waters, whose numbers of eggs and larval stages are quite low 
as in M. lanchesteri, M. brasiliense and M. hainanense. In other species, whose populations can be found in estuarine and continental areas, such as $M$. amazonicum, the effects of the estuary proximity can be similarly detected. The specimens' size, number of eggs and larval stages produced in estuarine populations are greater than those observed in continental populations (Odinetz-Collart and Rabelo 1996).

In this paper, the number of eggs of $M$. amazonicum individually was higher than that reported by Lobão et al. (1986), Da Silva et al. (2004) and Da Silva (2011) for different Brazilian regions and Gamba (1997) and Medina et al. (2008) for Venezuela, indicating that $M$. amazonicum specimens with similar total lengths show variable fecundity. According to Lobão et al. (1986), fecundity variations may be attributed to the different conditions of female maintenance in the laboratory, female's physiological conditions and season, among others. Nazari et al. (2003) explained that the fecundity is extremely associated with the female age in Macrobrachium species, thus increasing as it becomes mature.

Numerous studies on different decapods have shown that fecundity is closely related to female size (Wehrtmann and Lardies 1999; Oh et al. 2002; Nazari et al. 2003). As a general rule, larger females of the same species have larger ovaries and larger physical space available for egg attachment; consequently beingcapable of producing more offspring than smaller individuals (Oh et al. 2002; Nazari et al. 2003, Lara and Wehrtmann 2009). Probably, larger individuals have low growth rates, indicating that much of the available energy is devoted to egg production if compared to smaller individuals in whom a large fraction of the energy may be devoted to growth rather than egg production. In the present study, fecundity of $M$. amazonicum increased linearly with the female's size being similar to that observed by Medina et al. (2008) and Da Silva (2011), especially when considering embryos in early developmental stages, suggesting differences in the pattern of allocation of food energy by the animals at different sizes. Such a positive linear relationship has also been described for M. acanthurus (Valenti et al.1989; Tamburus et al. 2012), M. olfersi (Mossolin and Bueno 2002) and $M$. carcinus (Lara and Wehrtmann 2009), indicating a common characteristic in the Macrobrachium species.

Differences in the maximum reproductive output among crustacean species seem to be primarily the result of differences in female body size; however, other biotic or abiotic factors, such as egg size, latitudinal and seasonal variations, and habitat adaptation (Mantelatto and Fransozo 1997) may also influence the reproductive output. In this study, females of M. amazonicum with medium size converted between 4.8 and $21.85 \%$ of their body weight into eggs production, similar result to that observed for the big prawn M. carcinus by Lara and Wehrtmann (2009). This agrees with the findings reported for other Macrobrachium species, such as M. acanthurus with 14-30\% (Anger and Moreira 1998), M. hainanense with 4-17\% (Mantel and Dudgeon 2005) and M. olfersi with 7 38\% (Anger and Moreira 1998), indicating that reproductive output is variable in Macrobrachium species. The reproductive output of M. amazonicum was not related to the female size, and this finding is in accordance with the results reported for M. hainanense (Mantel and Dudgeon 2005) and M. carcinus (Lara and Wehrtmann 2009). Apparently, the reproductive output is associated with the individual condition of females and not size, since specimens of different sizes may have similar reproductive output.

\section{CONCLUSION}

Macrobrachium amazonicum females are more abundant that males in Mazagáo and Santana Island and may be being affected by differences in the occurrence of macrophytes and opportunities for refuge from predation. In this study the prawns are caught in abundance along the banks during low water, when they are migrating from the lowland. In Santana Island and Mazagáo $M$. amazonicum population shows a reproductive peak occurring in the rainy season, but reproduces continuously throughout the year. The number of juvenile prawns caught in this study indicates that the matapis in use has very closed cracks and can be affecting the local structure of $M$. amazonicum populations, given the considerably decreased volume and size of prawns caught reported by local fishermen.

Individual fecundity of $M$. amazonicum females is variable; it is higher in the Amazon River estuary than other Brazilian regions and is closely related to female size. The highest number of eggs of $M$. amazonicum produced individually indicates that specimens of Santana Island and Mazagão can be used as matrices in commercial larvae farming. The reproductive output was not related to the female size; there is a need for more studies to determine which factors actually affect the egg production in this species.

\section{ACKNOWLEDGMENTS}

We are grateful to God Almighty for the strength, knowledge and wisdom in researching and writing this article. Special thanks to the Empresa Brasileira de Pesquisa Agropecuária by supported the project MP3 1/2008 - No 03081470000 , whose research data provided the basis for the development of this work. We greatly thank to Instituto Chico Mendes de Conservaçáo da Biodiversidade for the collect authorization (SISBIO no 17702). Special thanks to our colleague Dr. Luis Takiyama for contributions given in the text and the English revision. 


\section{REFERENCES}

Anger, K.; Moreira, G. 1998. Morphometric and reproductive traits of tropical caridean shrimps. Journal of Crustacean Biology, 18: 823-838.

Antunes, L.S.; Oshiro, L.M.Y. 2004. Aspectos reprodutivos do camarão de água doce Macrobrachium potiuna (Crustacea, Decapoda, Palaemonidae) na Sena do Piloto, Mangaratiba, Rio de Janeiro, Brasil. Revista Brasileira de Zoologia, 21: 261-266.

Barros-Alves, S.P.; Almeida, A.C.; Fransozo, V.; Alves, D.F.R.; Da Silva, J.C.; Cobo, V.J. 2012. Population biology of shrimp Macrobrachium jelskii (Miers 1778) (Decapoda, Palaemonoidea) at the Grande River at northwest of the state of Minas Gerais, Brazil. Acta Limnologica Brasiliensia, 24: 266-275.

Bentes, B.S.; Martinelli, J.M.; Souza, L.S.; Cavalcante, D.V.; Almeida, M.C.; Isaac, V.J. 2011. Spatial distribution of the Amazon river prawn Macrobrachium amazonicum (Heller 1862) (Decapoda, Caridea, Palaemonidae) in two perennial creeks of an estuary on the northern coast of Brazil (Guajará Bay, Belém, Pará). Brazilian Journal of Biology, 71: 925-935.

Botelho, E.R.O.; Santos, M.C.F.; Souza, J.R.B. 2001. Aspectos populacionais do Guaiamum, Cardisoma guanhumi Latreille 1825, do estuário do Rio Una (Pernambuco - Brasil). Boletim Técnico Científico CEPENE, 9: 123-146.

Camargo M.; Leẫo, J.; Oliveira, A.; Márcio, A.; Silva, E.; Acácio, F.; Silva, G.; Sampaio, L.; Viana, M.; Antunes, T.; Silva, W. 2009. Matapi Pet: uma nova proposta para a exploração sustentável do camarão amazônico Macrobrachium amazonicum (Heller, 1862). Uakari, 5: 91-96.

Chaves, P.T.C.; Magalhães, C. 1993. O desenvolvimento ovocitário em Macrobrachium amazonicum (Heller, 1862) (Crustacea: Decapoda: Palaemonidae), camaráo dulcícola da Região Amazônica. Acta Amazonica, 23: 17-23.

Da Silva, R.R.; Sampaio, C.M.S.; Santos, J.A. 2004. Fecundity and fertility of Macrobrachium amazonicum (Crustacea, Palaemonidae). Brazilian Journal of Biology , 64: 489-500.

Da Silva, B.B. 2011. Ecologia, Pesca e Dinâmica populacional do camarão-da-Amazônia - Macrobrachium amazonicum (Heller, 1862) (Decapoda: Palaemonidae) - capturado na região das ilhas de Belém - Pará - Brasil. Tese de Doutorado, Universidade Federal do Pará, Belém-PA, 260p.

Deekae, S.N.; Abowei, J.F.N. 2010. The Recruitment Pattern of Macrobrachium macrobrachion (Herklots 1851) from Luubara Creek, Ogoni Land, Niger Delta, Nigeria. Research Journal of Applied Sciences, Engineering and Technology, 2: 568-573.

Fransozo, A.; Rodrigues, F.D.; Freire, F.A.M.; Costa, R.C. 2004. Reproductive biology of the freshwater prawn Macrobrachium iheringi (Ortmann, 1897) (Decapoda: Caridea: Palaemonidae) in the Botucatu region, São Paulo, Brazil. Nauplius, 12: 119 - 126.

Gamba, A.L. 1997. Biologia reproductiva de Macrobrachium jelskii (Miers, 1877) y Macrobrachium amazonicum (Heller, 1862) en Venezuela (Crustacea, Decapoda, Palaemonidae). Acta Científica Venezuelana, 48: 19-26.

Garcia-Dávila, C.R.; Alcantara, F.B.; Vasquez, E.R.; Chujandama, M.S. 2000. Biologia reprodutiva do camarão Macrobrachium brasiliense (Heller 1862) (Crustacea: Decapoda: Palaemonidae) em igarapés de terra firme da Amazônia peruana. Acta Amazonica, 30: 653 - 664.

Graziani, C.A.; Cheng, K.S.; De Donato, M. 1993. Comportamiento reproductivo y fertilidad de Macrobrachium carcinus (Decapoda: Palaemonidae) en Venezuela. Revista de Biología Tropical, 41: 657-665.

Lara, L.R.; Wehrtmann I.S. 2009. Reproductive biology of the freshwater shrimp Macrobrachium carcinus (L.) (Decapoda: Palaemonidae) from Costa Rica, Central America. Journal of Crustacean Biology, 29: 343-349.

Lobão, V.L., Rojas, N.E.; Valenti, W.C. 1986. Fecundidade e fertilidade de Macrobrachium amazonicum (Heller, 1862) (Crustacea, Decapoda) em laboratório. Boletim do Instituto de Pesca, 13: 15-20.

Maciel, C.R.; Valenti W.C. 2009. Biology, Fisheries, and Aquaculture of the Amazon River Prawn Macrobrachium amazonicum: A Review. Nauplius, 17: 61-79.

Mantel, S.K.; Dudgeon, D. 2005. Reproduction and sexual dimorphism of the palaemonid shrimp Macrobrachium hainanensein Hong Kong streams. Journal of Crustacean Biology, 25: 450-459.

Mantelatto, F.L.M.; Barbosa, LR. 2005. Populations structure and relative growth of freshwater prawn Macrobrachium brasiliense (Decapoda, Palaemonidae) from São Paulo State, Brazil. Acta Limnologica Brasiliensia, 17: 245-255.

Mantelatto, F.L.M.; Fransozo, L. 1997. Fecundity of the crab Callinectes ornatus Ordway, 1863 (Decapoda, Brachyura, Potunidae) from the Ubatuba region, São Paulo, Brazil. Crustaceana, 70: 214-226.

Mattos, L.A.; Oshiro, L.M.Y. 2009. Estrutura populacional de Macrobrachium potiuna (Crustacea, Palaemonidae) no Rio do Moinho, Mangaratiba, Rio de Janeiro, Brasil. Biota Neotropica, 9: $81-86$

Medina, J.C.P.; Severeyn Y.G.; Severeyn, A.F.H. 2008. Aspectos reproductivos del camarón Macrobrachium amazonicum (Heller) en la zona de Nazaret, San Rafael de El Moján, Lago de Maracaibo, Venezuela. Ciencia, 16, $402-408$.

Melo, A.G. 2003. Manual de identificação dos Crustacea Decapoda de água doce do Brasil. São Paulo, Ediçôes Loyola/Museu de Zoologia,USP, 430p.

Montoya, J.V. 2003. Freshwater shrimps of the Genus Macrobrachium associated with roots of Eichhornia crassipes (Water Hyacinth) in the Orinoco Delta (Venezuela). Caribbean Journal of Science, 39: $155-159$.

Moraes-Riodades, P.M.C.; Valenti, W.C. 2002. Crescimento relativo do camarão canela Macrobrachium amazonicum (Heller) (Crustacea, Decapoda, Palaemonidae) em viveiros. Revista Brasileira de Zoologia, 19: 1169-1176.

Mossolin, E.C.; Bueno, S.L.S. 2002. Reproductive biology of Macrobrachium olfersi (Decapoda, Palaemonidae) in Sáo Sebastiāo, Brazil. Journal of Crustacean Biology, 22: 367-376.

Nazari, E.M.; Simóes-Costa, M.S.Y.; Müller, M.R.; Ammar D.; Dias, M. 2003. Comparisions of fecundity, egg size, and egg 
mass volume of freshwater prawns Macrobrachium potiuna and Macrobrachium olfersi (Decapoda, Palaemonidae). Journal of Crustacean Biology, 23: 862-868.

New, M.B. 2002. Farming freshwater prawns: a manual for the culture of the giant river prawn (Macrobrachium rosenbergii). FAO Fisheries Technical Paper, no. 428. 212p.

Odinetz-Collart, O. 1991. Stratégie de reproduction de Macrobrachium amazonicum en Amazinie Centrale. Crustaceana, 61: 253-270.

Odinetz-Collart, O.; H. Rabelo. 1996. Variation in egg size of the fresh-water prawn Macrobrachium amazonicum (Decapoda: Palaemonidae). Journal of Crustacean Biology, 16: 684-688.

Oh, C. W., Suh, H. L.; Park, K. Y.; Ma, C. W.; Lim. H. S. 2002. Growth and reproductive biology of the freshwater shrimp Exopalaemon modestus (Decapoda: Palaemonidea) in a Lake of Korea. Journal of Crustacean Biology, 22: 357-366.

Phone, H.; Suzuki, H.; Ohtomi, J. 2005. Reproductive biology of the freshwater palaemonid prawn, Macrobrachium lanchesteri (De Man,1911) from Myanmar. Crustaceana, 78: 201-213.

Sampaio, C.M.S.; Silva, R.R.; Santos, J.A.; Sales, S.P. 2007. Reproductive cycle of Macrobrachium amazonicum females (Crustacean, Palaemonidae). Brazilian Journal of Biology, 67: 551-559.

Silva, K.C.A.; Cintra, I.H.A.; Muniz, A.P.M. 2005. Aspectos bioecológicos de Macrobrachium amazonicum (Heller, 1862) a jusante do reservatório da hidrelétrica de Tucuruí, Pará. Boletim Técnico-Científico do CEPNOR, 5: 55-71.

Silva, K.C.A.; Souza, R.A.L.; Cintra, I.H.A. 2002. Camarãocascudo Macrobrachium amazonicum (Heller, 1862) (Crustacea,
Decapoda, Palaemonidae) no município de Vigia, Pará, Brasil. Boletim Técnico-Científico do CEPNOR, 2: 41-73.

Silva, M.C.N.; Frédou, F.L.; Souto-Filho, J. 2007. Estudo do crescimento do camarão Macrobrachium amazonicum (Heller, 1862) da Ilha de Combú, Belém, Estado do Pará. Amazonia: Ciência e Desenvolvimento, 2: 85-104.

Simonian, L.T.L. 2006. Pescadores de camarão: gênero, mobilização e sustentabilidade na ilha Trambioca, Barcarena, PA. Boletim do Museu Paraense Emílio Goeldi-Ciências Humanas, 1: 35 - 52.

Tamburus, A.F.; Mossolin, E.C.; Mantelatto, F.L. 2012. Populational and reproductive aspects of Macrobrachium acanthurus (Wiegmann, 1836) (Crustacea: Palaemonidae) from North Coast of São Paulo State, Brazil. Brazilian Journal of Aquatic Science and Technology, 16: 9-18.

Valenti, W.C., Cardoso, J.; V. Lobão. 1989. Fecundidade em Macrobrachium acanthurus (Wiegmann, 1836) do Rio Ribeira de Iguape (Crustacea, Decapoda, Palaemonidae). Revista Brasileira de Zoologia, 6: 9-15.

Zar, J.H. 1999. Biostatistical analysis. Pretice-Hall, Upper Saddle River, 662p.

Wehrtmann, I.S. 1990. Distribution and reproduction of Ambidexter panamense and Palaemonetes schmittiiin Pacific Costa Rica (Crustacea, Decapoda). Revista de Biología Tropical, 38: 327329.

Wehrtmann, I.S.; Lardies, M. 1999. Egg production of Austropandalus grayi (Decapoda, Caridea, Pandalidae) from the Magellan region, South America. Scientia Marina 63: 325-331

Recebido em 05/04/2013

Aceito em 20/08/2013 